\title{
Engr. Abdulkadir Abdullahi Kure Ultra-Modern Market Fire Safety Assessment
}

\author{
Fatemeh Nouban and Nura Yunusa \\ Faculty of Civil and Environmental Engineering \\ Near East University, 99138 Nicosia (via Mersin 10, Turkey), Cyprus.
}

\begin{abstract}
Nigeria has been affected by urban fire incidences especially the markets inferno which has an enormous cost to the businesses. The incidence seems to be yearly occurrences especially Engr. A.A. Kure UltraModern Market fire outbreak which began in 2014 and repeatedly continues every year which disrupts the market activities and causes environmental hazard such as pollution. The incidence occurrence is likely perceived to be connected to the lack of following due building process or fire safety regulation procedures during the market construction. In recognizing that some certain responses needed to prevent or curtail the reoccurrences of fire incidences, the study evaluates Engr. Abdulkadir Abdullahi Kure Ultra-Modern Market fire safety by considering mitigation or prevention regulations. Based on the 2019 updated England Building Regulations, the study assessed the Engr. Abdulkadir Abdullahi Kure Ultra-Modern Market fire safety using observable and measurable criteria such as means of warning and fire protection devices, internal and external fire spreading, fireresisting doors and fire service facilities and layout accessibility. The study revealed the drawback in legislating the fire safety regulations in the country. The regulatory bodies responsible for construction control and regulations should ensure the compliances with fire safety regulation to prevent further loss of resources and human lives in the country. The study, however, recommended that construction regulations agencies in the country need to use some set of safety indicators, as shown in the study, to evaluate the fire safety of any construction work.
\end{abstract}

Keywords:- Fire Safety, Market Fire, Fire Incidence, Construction Regulation, Nigeria.

\section{INTRODUCTION}

Fire disaster has remained the major threat for the environment which has the potential consequential effect to the human and environmental, resources and causes the collapse of the structures as fire outbreak has always remained a major and quite frequent hazard for civil constructions yet most fires are preventable and controllable. Thus, prevention and control of fire outbreak and spreading have remained a top priority issue in the built environment. In the event of fire outbreak, building design and layout, style and material used for construction play a vital role in preventing the spread of fire and smoke, and alerting the potential danger. Ensuring suitable fire safety design, building techniques and material are used are the responsible architects, designers, contractors, developers and the owners which necessitated the construction standard legislation through enhancing i.e. harmonizing and involving the all construction industries stakeholders in the application of standard management quality guide [1]. Thereby neglecting or lack of applying suitable standard and paying no attention to the frequent changes in the building environment are the major causes of fire incidences.

Nigeria has been affected by urban fire incidences especially the markets inferno which has an enormous cost to the businesses. The incidence seems to be yearly occurrences especially Engr. Abdulkadir Abdullahi Kure Ultra-Modern Market fire outbreak which began in 2014 and repeatedly continues every year which disrupts the market activities and causes environmental hazard such as pollution. The incidence occurrence is likely perceived to be connected to lack of following due building process or following fire safety regulation procedures during the market construction as a result of occurrences of such scenario and their likes Nigeria has been ranked as first by the World Health Organisation [2] in the world for death by fire, not because of incident rates in the country but power surge and outages frequently, electricity sparks, lack of smoke alarms, fire extinguisher, electricity breaker, fire blankets and indicated routes for escape, and regular fire drills which will help in exposing the deficiency or poor fire detection, prevention and escaping techniques. All these are attributed to the lack of legislation construction standard and regulation or compliances to the legislation in the country, thereby, designing and constructing improperly, improper fitting of electricity, the illegal connection of electricity and use of substandard material in construction. Thus, triggered the outbreak. However, it is possible to change the paradigm of construction activities in Nigeria from traditional and conservative construction into safety culture and the construction standard legislation are keys to achieving any change in the construction practices because of fire incidence in Nigeria are always connected to the ignorance of construction know-how while regulations will allow new design and construction concepts and technology to be explored and adopted in the building environment to curb any potential fire outbreak in the country. Therefore, the newly adopted construction methods conform with the safety standards legislation [3] in form construction code which is either absent or outdated and not backed by the Nigerian law [4] while in other countries the demand for a 
sustainable built environment such as accessibility, comfort and energy efficiency are made [3]. The part 8 of BS5950 [5] of British Standard considered as a first national fire engineering practicing code to provide a wide range of fire safety guides which is widely adopted by several countries. The standard recommends fire resistance derived from test and calculation which are presented in clause 4.3 part 20 and 21 of BS476 [6] while safety in the design, management and use of the residential building and new non-residential buildings Code of Practice where provided in BS 9991:2015 and BS 9999:2017 respectively. Furthermore, volume 2 of Approved Document B Fire Safety (Buildings Other than Dwellings) of 2010 England building Regulations which is updated 2019 covers specified requirement for fire safety [7]. Additionally, Part 1.2 of both Eurocode 3 and 4 presents a complete set of structural fire engineering design approaches and methods. [8-9]. Similarly, the Code of Practice on Fire Resistant Construction Hong Kong [10-11] recommends provisions for mitigating the fire effect on the construction by preventing the fire spread.

Construction standards and regulations are the conformity of set minimum requirements and standards throughout the construction phases for the accessible, sustainable and efficient resources achievement [12]. Therefore, the effective fire control is based upon enforcing the construction standard regulations where the proper design approach, construction concept and techniques and quality of materials are given much consideration among others. Therefore, this research intends to assess Engr. Abdulkadir Abdullahi Kure Ultra-Modern Market, Niger State to assess the fire safety standard of the market using the indicators based volume 2 of Approved Document B Fire Safety (Buildings Other than Dwellings) of 2010 England building Regulations which is updated 2019 covers specified requirement for fire safety to provide a recommendation on fire safety standard to the relevant authorities in making inform-decision on curbing and mitigating the fire outbreak in the country and why fire standard must be legislated.

\section{METHOD AND MATERIALS}

\section{* Average Annual Pit Hole Size (PS)}

\section{A. Average Annual Pit Hole (PS)}

Abdulkadir Abdullahi Kure Ultra-Modern Market (Figure 1) is the largest market with 36 hectares' land designed and constructed by Urban Shelter to accommodate 6,364 shops [13] located in Chanchaga Local Government.

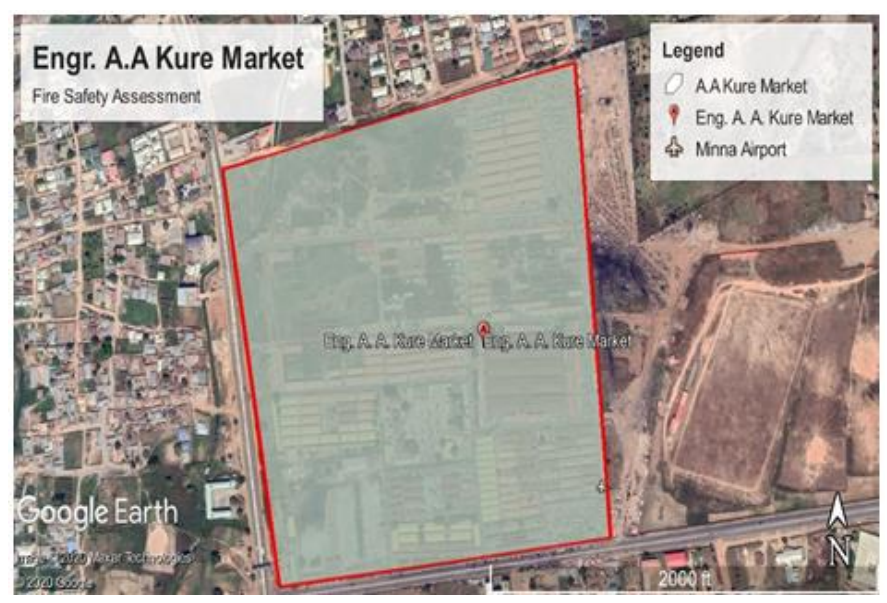

Fig 1:- Engr. Abdulkadir Abdullahi Kure Ultra-Modern Market

Pit Chanchaga (Figure 2), the metropolitan area of Minna, is a Local Government Area in Niger State, Nigeria covers $72 \mathrm{~km} 2$ (28 sq mi) [14], located between the 6o30'E6o40'E Longitude and 9030’N-9o35'N Latitude.

The 2006 population of Chanchaga Local government was projected for 2020 to approximately 309,154 population using the average growth rate of $3.06 \%$ [15] based on the recommended National Population Commission exponential method of projection [14] as a result of the inadequacies of Nigeria's Census data, the exponential method will give high variance.

$$
P t=P_{0} e^{k t}
$$

Pt is the projected population.

$\mathrm{P}_{0}$ is the initial population

$\mathrm{t}$ is time

$\mathrm{k}$ is the growth rate

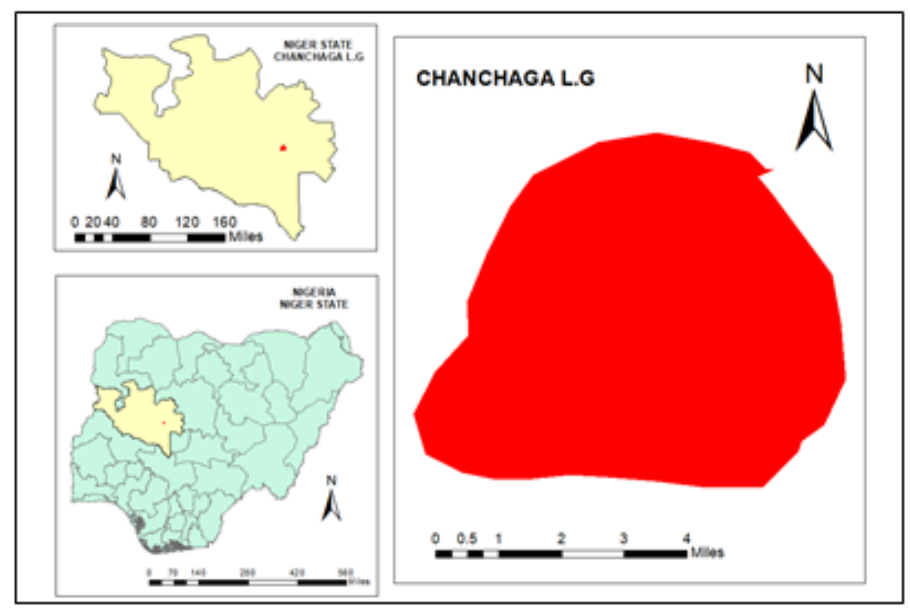

Fig 2:- Map Showing Chanchaga Local Government, Niger State, Nigeria 
Although, Engr. Abdulkadir Abdullahi Kure UltraModern Market shops are not equal, three main shops design patterns are identified (Figure 3, 4 and 5), shops are presented in a grid layout and repetitive pattern, each group shops (Figure 6).

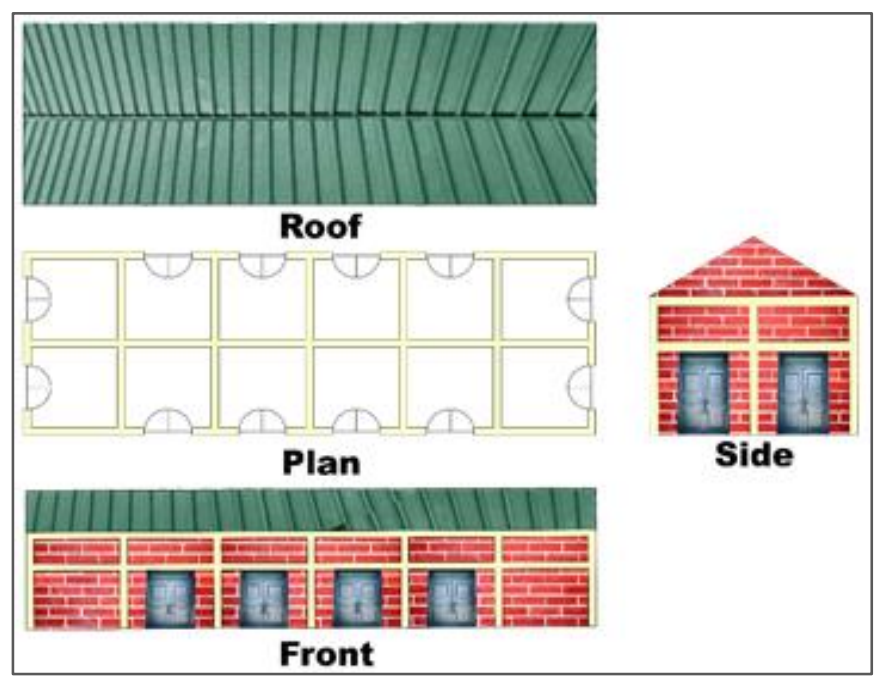

Fig 3:- Engr. Abdulkadir Abdullahi Kure Ultra-Modern Market Shops Design Pattern-1

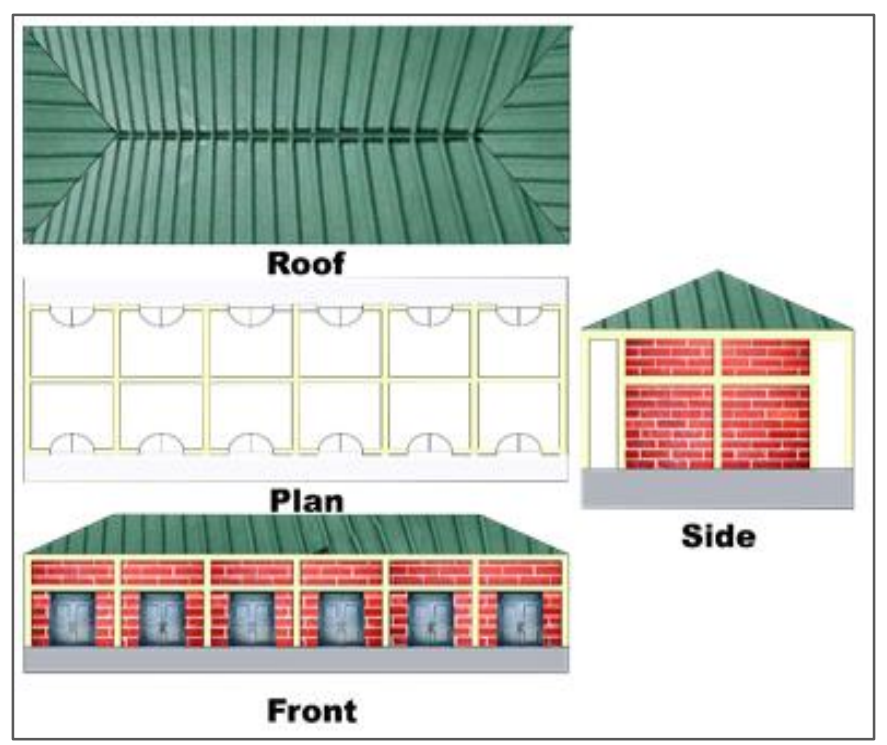

Fig 4:- Engr. Abdulkadir Abdullahi Kure Ultra-Modern Market Shops Design Pattern-2

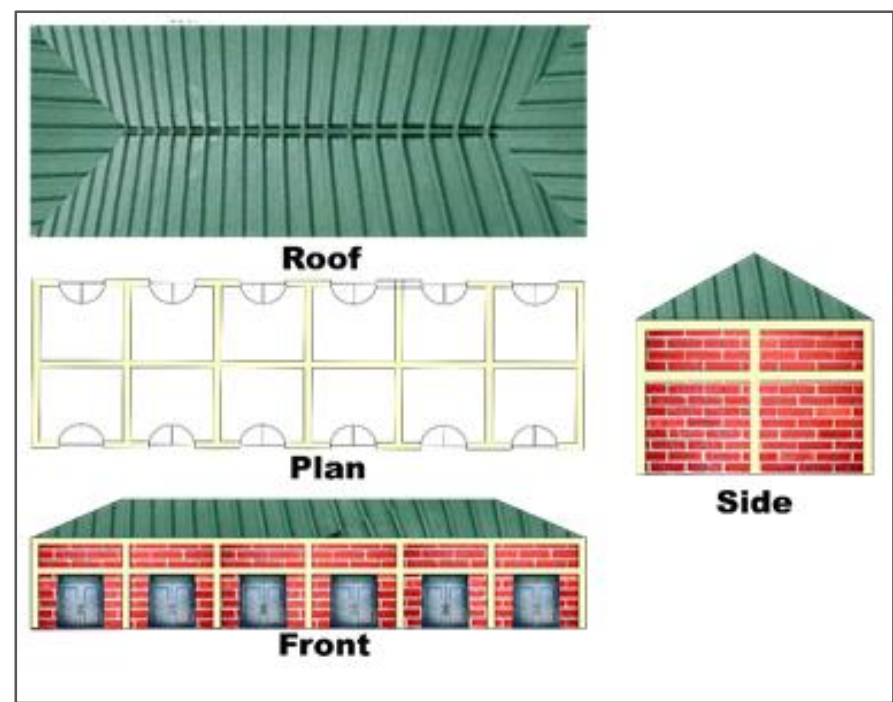

Fig 5:- Engr. Abdulkadir Abdullahi Kure Ultra-Modern Market Shops Design Pattern-3

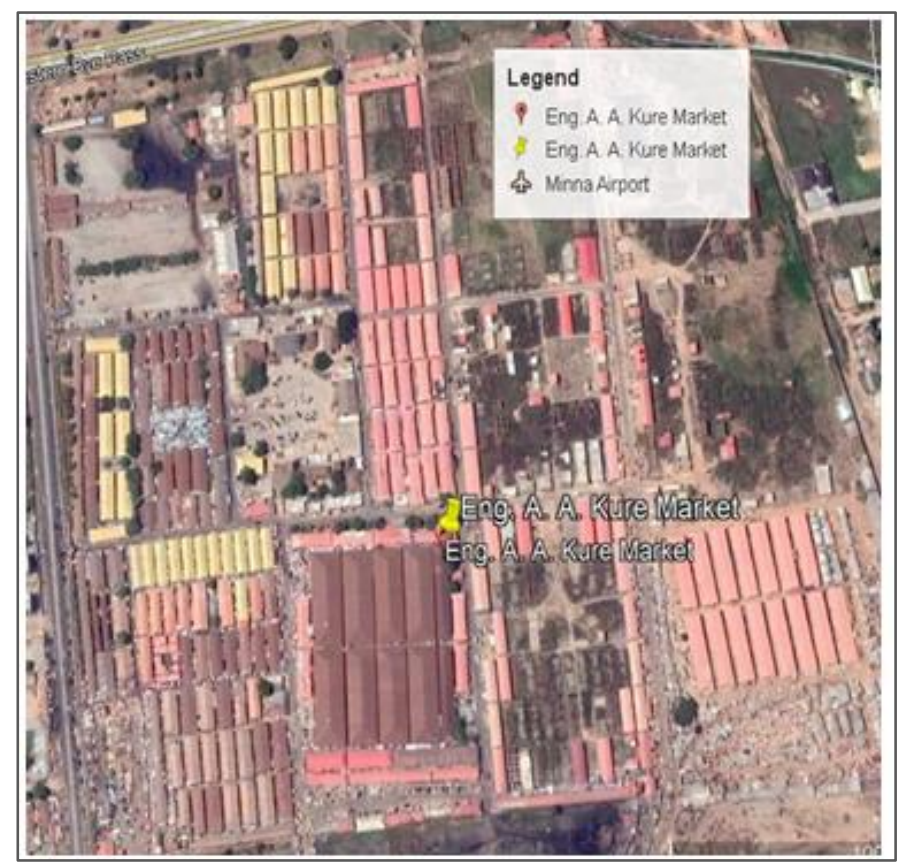

Fig 6:- Engr. Abdulkadir Abdullahi Kure Ultra-Modern Market Shops Grid Layout

The incidence of Engr. Abdulkadir Abdullahi Kure Ultra-Modern Market fire outbreak (Figure 7) seems to be an unending problem, a perennial issue. The incidence which began in 2014 continues to happen every year repeatedly between November and January disrupting business activities and reducing the market productivity output causing lost as a result of enormous cost presented in Table 1. 


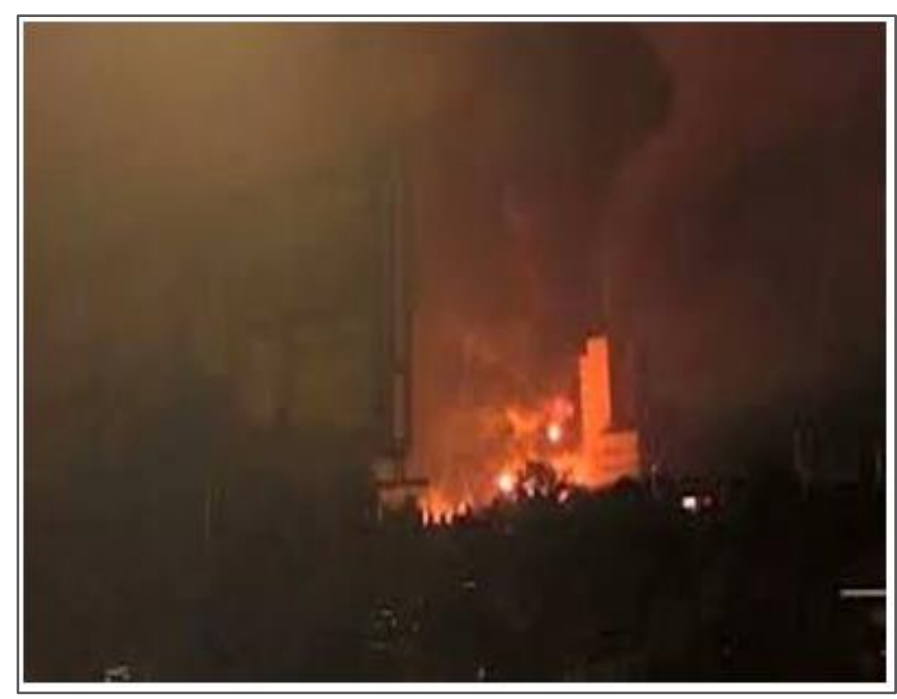

Fig 7:- Engr. Abdulkadir Abdullahi Kure Ultra-Modern Market Shops Grid Layout.

\begin{tabular}{|c|c|c|}
\hline Year & Affected Shops & Value of Properties Lost (\$) \\
\hline 2014 & No Data & $174,418[17]$ \\
\hline 2015 & No Data & No Data \\
\hline 2016 & 50 & Billions of Naira [18] \\
\hline 2017 & $16[19]$ & No Data \\
\hline 2018 & No Data & No Data \\
\hline 2019 & 70 & 1.9million [20] \\
\hline
\end{tabular}

Table 1:- Engr. Abdulkadir Abdullahi Kure Ultra-Modern Market Fire Outbreak History

Although the major cause of the outbreak was not yet ascertained, dry weather was identified as a major cause due to the lack of compliances to the construction standard and regulation help in spreading the fire throughout the market. In recurrences of Engr. Abdulkadir Abdullahi Kure UltraModern Market fire incidences, the authority has primary responsibility for legislating the fire safety regulation by enhancing a good system that measures the physical level and measurement interaction collectively to obtain a comprehensive fire safety system standard. Moreover, Nigeria fire service poor responsiveness and lack of equipped firefighting systems identified as the most common factor contributing to fire widespread in the market beyond where the fire originated. In recognizing that some certain responses needed to prevent or curtail the reoccurrences of fire incidences, the study evaluates Engr. Abdulkadir Abdullahi Kure Ultra-Modern Market fire safety by considering mitigation or prevention regulations.

\section{B. Approach}

Based on the 2019 updated England Building Regulations, the study assessed the Engr. Abdulkadir Abdullahi Kure Ultra-Modern Market fire safety using the following observable and measurable criteria:

\section{$>$ Means of Warning and Fire Protection Devices}

To preserve the safety of Engr. Abdulkadir Abdullahi Kure Ultra-Modern Market the following safety system must be available to curb or mitigate the potential fire outbreak in the market:

- Smoke and emergency light alarm

- Water sprinkle

- Electricity breaker in case of electricity surge, frequent outage or sparks

\section{$>$ Internal Fire Spreading}

Wall and ceiling materials used in Engr. Abdulkadir Abdullahi Kure Ultra-Modern could significantly contribute to internal fire growth.

\section{External of Fire Spreading}

Engr. Abdulkadir Abdullahi Kure Ultra-Modern Market's shops have adjoined the potential of fire spreading externally evident. The external walls and roof must be adequate to resist the spread of fire especially the roof decking which made of timber has the potential of spreading the fire horizontally from the shop where the fire originated from to the other shops. Therefore, the fire separation between the adjoined shops must be effectively achieved to inhabit the fire and smoke from spreading beyond the shop where the fire originated.

\section{Fire Resisting Door}

The external doors of the should not be a medium of fire spreading, the door must be able to contain the outbreak before the arrival of firefighters. The door must be professionally fitted.

\section{Access and Facilities for Fire Service}

Engr. Abdulkadir Abdullahi Kure Ultra-Modern Market must have fire responding facilities such as standpipe firefighting for the fast responding to any potential fire outbreak and layout must be achieved for easy access by the firefighters in case of any emergency response.

The above indicators are scored 1 to 3 as fire control rating scales. 1 means controlled and 3 means least or inadequately controlled. The detailed description is presented in the table below: 
ISSN No:-2456-2165

\begin{tabular}{|c|c|c|c|}
\hline \multirow{2}{*}{ Criteria } & \multicolumn{2}{|c|}{ Description } & 3 \\
\cline { 2 - 4 } & Adequately Provided & Provided & Not Provided \\
\hline Means of Warning & Control & Fairly Control & Poorly Control \\
\hline Internal Fire Spreading & Control & Fairly Control & Poorly Control \\
\hline External of Fire Spreading & $\begin{array}{c}\text { Fire Resisting Door Provided. } \\
\text { Fire Resisting Door }\end{array}$ & $\begin{array}{c}\text { Fire Resisting Door Not } \\
\text { Provided. } \\
\text { Adequately Fitted. }\end{array}$ & $\begin{array}{c}\text { Fire Resisting Door Not Provided. } \\
\text { Not Adequately Fitted. }\end{array}$ \\
\hline $\begin{array}{c}\text { Access and Facilities for } \\
\text { Fire Service }\end{array}$ & Provided and Accessible & $\begin{array}{c}\text { Not Provided but } \\
\text { Accessible }\end{array}$ & Not Provided and not Accessible \\
\hline
\end{tabular}

Table 2:- Engr. Abdulkadir Abdullahi Kure Ultra-Modern Market Fire Safety Rating Criteria

Since there are 5 indicators, however, the highest possible score against the neediest indicator will be 30 .
Therefore, the study developed the following score bracket for the grading and description of each grade $-\mathrm{A}$ to $\mathrm{C}$.

\begin{tabular}{|c|c|c|c|}
\hline Score & Indicators & Grade & Description \\
\hline $20-30$ & 3 & A & Inadequate \\
\hline $10-19$ & 2 & B & Fairly \\
\hline $01-09$ & 1 & C & Adequate \\
\hline
\end{tabular}

Table 3:- Engr. Abdulkadir Abdullahi Kure Ultra-Modern Market Fire Safety Scoring And Grading

To achieve the above fire safety rating and scoring, fire safety regulations, participatory data and GIS are used to the fire safety of Engr. Abdulkadir Abdullahi Kure Fire Safety to establish a baseline so that the rating and soring can be measured more precisely.

\section{RESULT AND DISCUSSION}

\begin{tabular}{|c|c|c|c|}
\hline S/N & Criteria & Grade & Justification \\
\hline $\mathbf{l}$ & $\begin{array}{c}\text { Means of Warning and Fire } \\
\text { Protection Devices }\end{array}$ & A & $\begin{array}{c}\text { There is a complete absence of fire warning and } \\
\text { protection devices to alert and prevent any potential } \\
\text { fire outbreak or to extinguish the fire from spreading } \\
\text { to the other shops beyond where the fire originated in } \\
\text { the market. }\end{array}$ \\
\hline $\mathbf{2}$ & Internal Fire Spreading & A & $\begin{array}{l}\text { Although the intermal are adequately lined up with red } \\
\text { bricks considered as the best construction materials } \\
\text { highly resistant to fire; highly effective in controlling } \\
\text { internal fire spreading, however, fiber ceiling material } \\
\text { used very poor in resisting the spread of fire internally } \\
\text { and even externally. }\end{array}$ \\
\hline $\mathbf{3}$ & External of Fire Spreading & A & $\begin{array}{l}\text { Poorly fire resisting ceiling materials (Figure 8) } \\
\text { contributed to the external fire spreading by extending } \\
\text { fire decking especially which are made from of } \\
\text { timber. Furthermore, lack of horizontal roof separation } \\
\text { between the adjoined shops (Figure 9 and 10) was not } \\
\text { achieved effectively to inhabit the fire and smoke from } \\
\text { spreading beyond the shop where the fire originated. }\end{array}$ \\
\hline $\mathbf{4}$ & $\begin{array}{l}\text { Fire Resisting Door } \\
\text { fire resisting doors are not adequately provided and } \\
\text { steel which lack of capability to contain the fire within } \\
\text { the arrival of the fire services }\end{array}$ \\
\hline $\mathbf{5}$ & $\begin{array}{c}\text { Access and Facilities for } \\
\text { Fire Service }\end{array}$ & A & $\begin{array}{l}\text { The market is accessible in case of any emergency, } \\
\text { however, fire service facilities are not provided. }\end{array}$ \\
\hline
\end{tabular}

Table 4:- Engr. Abdulkadir Abdullahi Kure Ultra-Modern Market Fire Safety Evaluation Result 


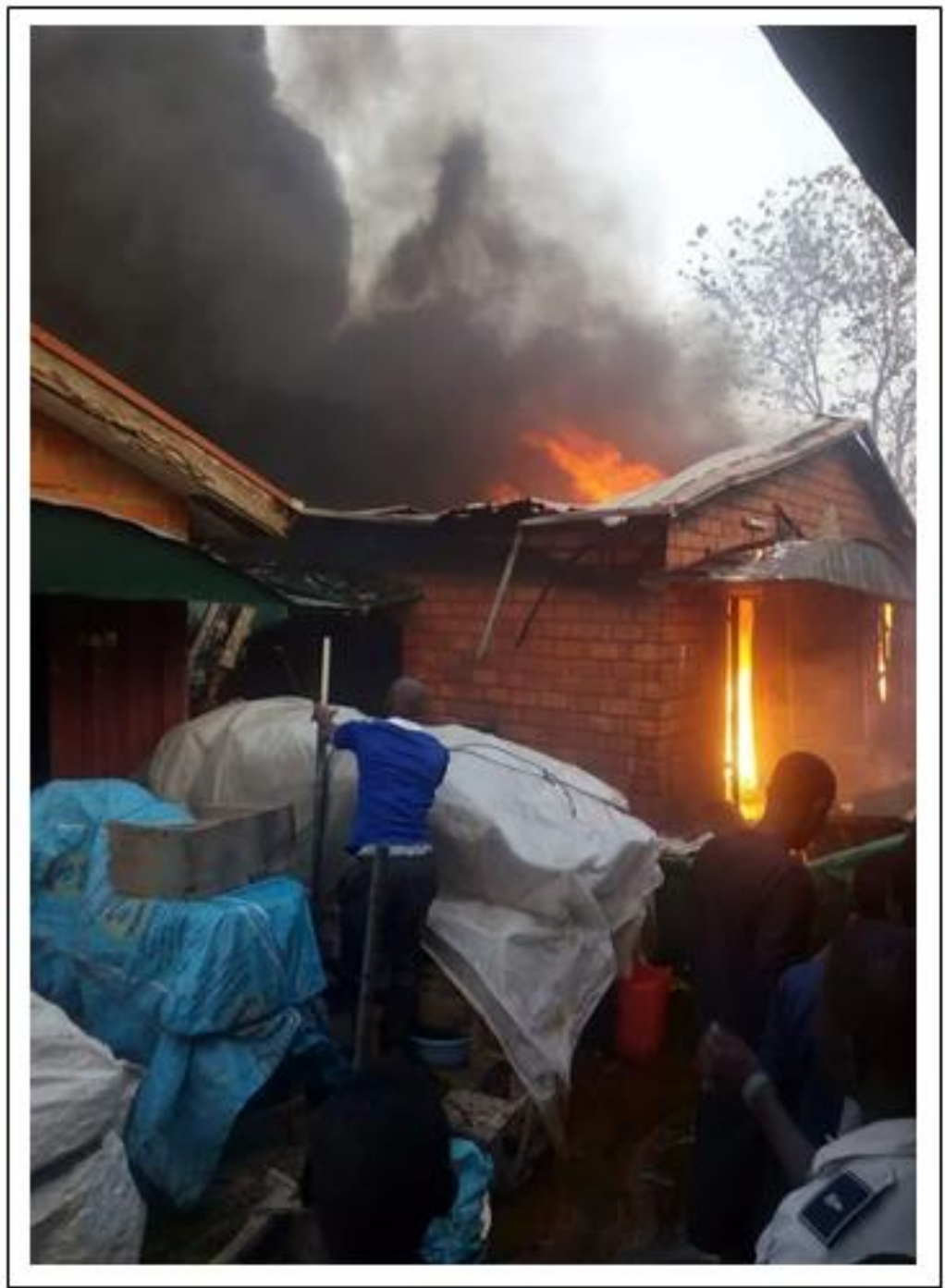

Fig 8:- Engr. Abdulkadir Abdullahi Kure Ultra-Modern Market Fire Spreading [16]

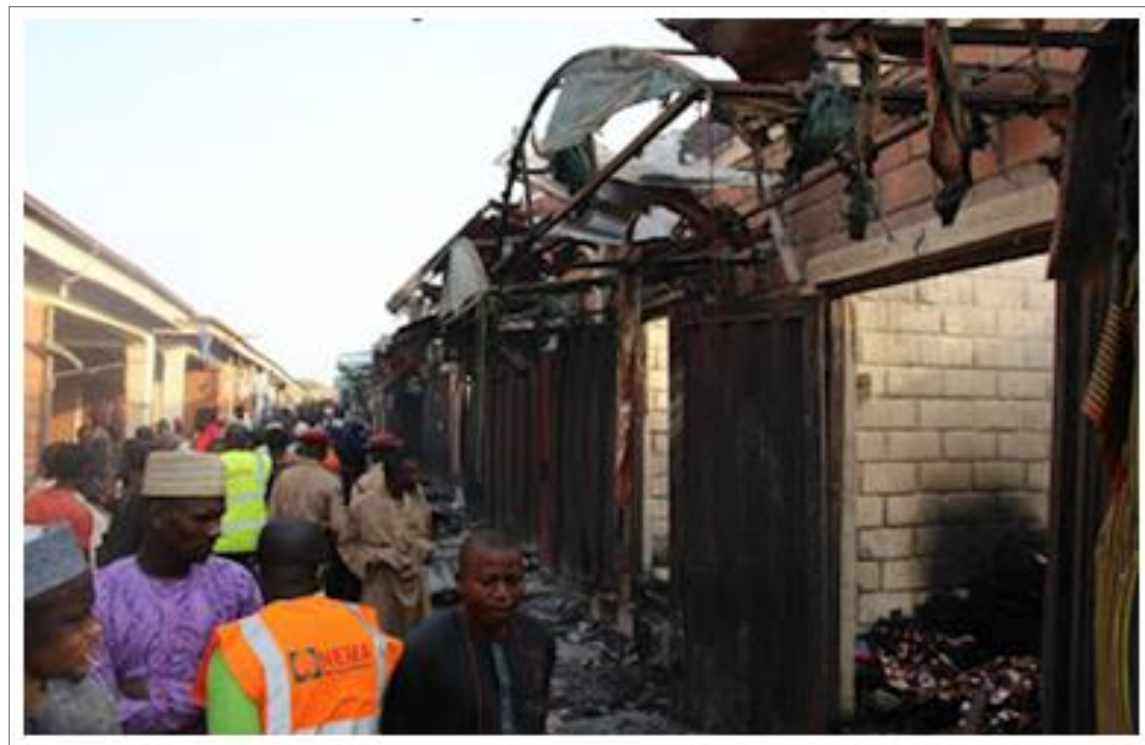

Fig 9:- Engr. Abdulkadir Abdullahi Kure Ultra-Modern Market Shops Doors After External Fire Spreading [16] 


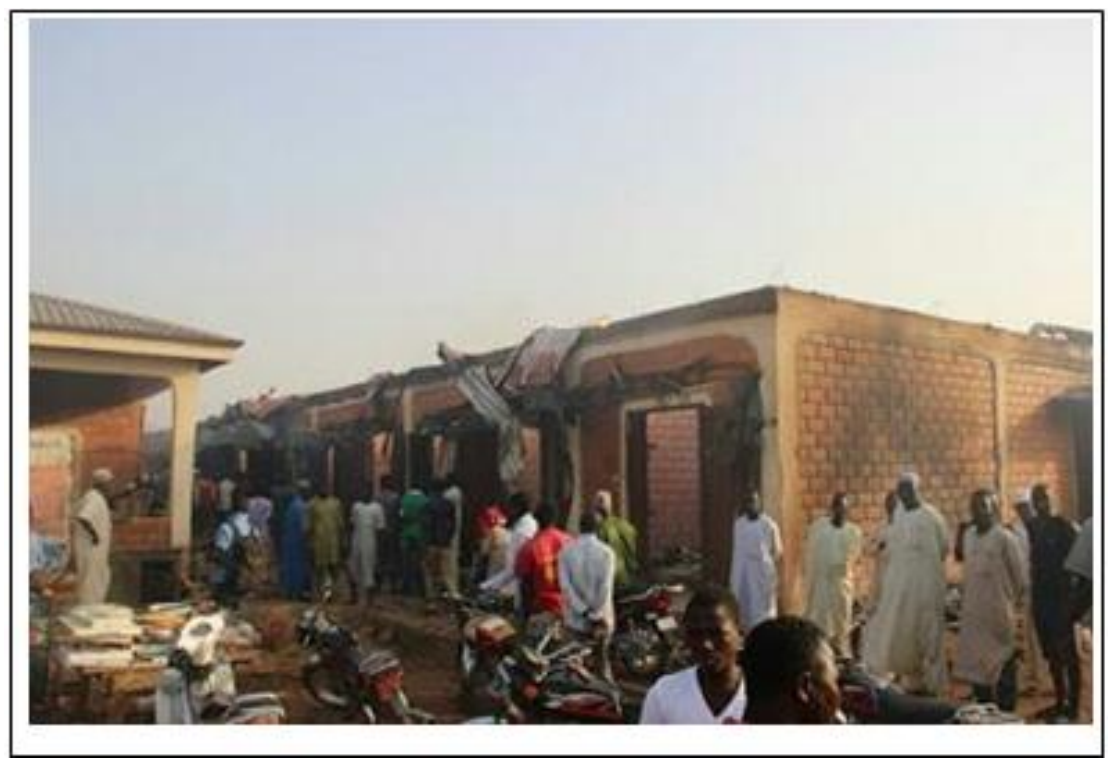

Fig 10:- Engr. Abdulkadir Abdullahi Kure Ultra-Modern Market Roofs After External Fire Spreading

\section{CONCLUSION}

The study found that most of Engr. Abdulkadir Abdullahi Kure ultra-Modern Market fire incidences and fire spreading is triggered by the absence of or failure in compliance with construction standards or regulations that require a competent person to completes a fire risk assessment or evaluation by considering all aspects of fire safety, including the design and construction in conjunction with the materials used. Therefore, Engr. Abdulkadir Abdullahi Kure ultra-Modern Market fire outbreak preparedness is based on the fire prevention or fire control knowledge and fire prevention or control legislation enforcement which enforce the identification of all the potential fire outbreak and conduct an effective fire safety assessment of the adequate measures considered, provided or needed in the built environment.

This study revealed the drawback in legislating the fire safety regulations in the country. The regulatory bodies responsible for construction control and regulations should ensure compliance with fire safety regulation to prevent further loss of resources and human lives in the country.

The study, however, recommended that construction regulations agencies in the country need to use some set of safety indicators, as shown in the study, to evaluate the fire safety of any construction work, this will help in recognizing all potential fire hazard effectively in the built environment and effective way to achieving a fire safety management in Nigeria which requires the fire outbreak prevention or fire control regulation that aims to guarantee the application and enforcement of minimum fire safety requirements and standards in the form of legislation or codification enactment by the government regulatory agency.

\section{REFERENCES}

[1]. Ruya, F., Chitumu, D., \& Jatau, T. S. (2017). Construction standard and regulation in Nigeria. FIG Working Week 2017 Surveying the World of Tomorrow - From Digitalisation to Augmented Reality, Helsinki, Finland, 29 May-2 June, 2017. [Online] Available at https://www.fig.net/resources/proceedings/fig_procee dings/fig2017/papers/ts07d/TS07D_fadason_danladi_ et_al_8746.pdf on 10 February, 2019

[2]. World Health Organisation. (2016). World Health Statistics 2016: Monitoring Health for the SDGs, Sustainable Development Goals. Available at https://www.who.int/gho/publications/world_health_st atistics/2016/EN_WHS2016_AnnexB.pdf?ua=1.

Retrieved on July 3, 2020.

[3]. Meijer, F., \& Visscher, H. (2014). Building control: Private versus public responsibilities. [Online] Available at https://www.researchgate.net/publication/27346937_B uilding_control_private_versus_public_responsibilitie s on 10 January, 2019.

[4]. Omenihu, F. C., Onundi, L. O., \& Alkali, M. A. (2016). An Analysis of Building collapse in Nigeria (1971-2016): Challenges for stakeholders. Annals of Borno, XXVI, pp. 113-140.

[5]. British Standards Institution. (1990) BS5950 Structural use of steelwork in building. Code of practice for fire resistant design.

[6]. British Standards Institution. BS 476. (1987). Method for determination of the fire resistance of elements of construction (general principles).

[7]. The Building Regulations. (2010). UK Statutory Instruments. No. 2214, Part 8, Regulation 38. Available at http://www.legislation.gov.uk/uksi/2010/2214/content s/made Retrieved on July 3, 2020. 
[8]. British Standards Institution. DD ENV 1993-1-2: (2001) Eurocode 3: Design of steel structures - Part 1.2: General rules - Structural fire design (together with United Kingdom National Application Document). British Standards Institution (1995).

[9]. British Standards Institution. prEN 1994-1-2: (2002) Eurocode 4: Design of composite steel and concrete structures - Part 1.2: General rules Structural fire design.

[10]. Building Authority, the Government of Hong Kong. (1996). Code of Practice on Fire Resistant Construction.

[11]. Code of Practice on Fire Resistant Construction (1996), Building Authority, the Government of Hong Kong.

[12]. Inter-jurisdiction Regulatory Collaboration Committee (IRCC). (2010). Performance-based building regulatory systems: Principles and experiences. Meacham, B. J. (ed.), pp. 1-174. [Online] Available at https://www.wpi.edu/sites/default/files/docs/Departme nts-Programs/Fire-Protection/IRCC_Final_PDF.pdf on 16 June, 2019.

[13]. Urban Shelter and Infrastructure. Engr. A.A. Kure Ultra-Modern Market \& Park. Retrieved on June 25, 2020.

From http://www.urbanshelterinfrastructure.com/portfolio/e ngr-a-a-kure-ultra-modern-market-park/

[14]. National Bureau of Statistics. (2011). Annual Abstract of Statistics. Available on http://istmat.info/files/uploads/53129/annual_abstract_ of_statistics_2011.pdf. Retrieved on July 3, 2020.

[15]. Macrotrends. Minna, Nigeria Metro Area Population 1950-2020. Retrieved on June 25, 2020. From https://www.macrotrends.net/cities/23540/minna/popu lation

[16]. This Day Live. (2019). Abdulkhadir Kure Market Gutted by Fire. Retrieved on June 27, 2020, from https://www.thisdaylive.com/index.php/2019/01/04/ab dulkhadir-kure-market-gutted-by-fire/

[17]. All Africa Online Newspaper. (2014). Nigeria: N30 Million Worth of Goods Lost to Minna Market Fire. Retrieved on June 27, 2020 from https://allafrica.com/stories/201401080278.html

[18]. Channels TV. (2016). Fire Guts Abdulkadir Kure Market In Minna. Retrieved on June 27, 2020, from https://www.channelstv.com/2016/01/03/fire-gutsabdulkadir-kure-market-in-minna/

[19]. Traders lament as fire guts Kure Market in Minna. (2017). Punch Online Newspaper. Retrieved on June 27, 2020 from https://punchng.com/traders-lamentfire-guts-kure-market-minna/

[20]. The Nation Online Newspaper. (2019). Updated: Fire guts 70 Shops in Minna Market. Retrieved on June 27, 2020, from https://thenationonlineng.net/updated-fireguts-70-shops-minna-market/ 